International Journal of Canadian Studies

Revue internationale d'études canadiennes

INTERNATIONAL JOURNAL OF CANADIAN STUDIES

REVUE INTERNATIONALE D'ÉTUDES CANADIENNES

\title{
The Only Canadians: Canada's French and the British Connection
}

\section{Katherine L. Morrison}

Numéro 37, 2008

Canadian Challenges

Les défis canadiens

URI : https://id.erudit.org/iderudit/040800ar

DOI : https://doi.org/10.7202/040800ar

Aller au sommaire du numéro

Éditeur(s)

Conseil international d'études canadiennes

ISSN

1180-3991 (imprimé)

Découvrir la revue

Citer cet article

Morrison, K. L. (2008). The Only Canadians: Canada's French and the British Connection. International Journal of Canadian Studies / Revue internationale d'études canadiennes, (37), 177-194. https://doi.org/10.7202/040800ar

\section{Résumé de l'article}

Le Canada perpétue depuis longtemps deux mythes, à savoir le loyalisme et la conquête. La nature de ces mythes ainsi que leur fondement historique et la ténacité de leurs liens réciproques sont examinés ici. Dans les premières années du Canada, le terme « Canadien » désignait exclusivement des Canadiens français, alors qu'on appelait les Canadiens anglais, des Britanniques. La présente étude démontre, selon un ordre chronologique et à l'aide d'exemples littéraires replacés dans le contexte de leur époque, le ressentiment des Canadiens français à l'égard du loyalisme dont faisaient preuve leurs compatriotes anglophones. Est-ce que l'adhésion du Canada à la monarchie britannique divise toujours le Canada et l'empêche d'avoir un sens de nationalité commune? 


\title{
Katherine L. Morrison
}

\section{The Only Canadians: Canada's French and the British Connection}

\begin{abstract}
Canada has two long-standing national myths: Loyalism and the Conquest. The nature of these myths, their historical founding, and the tenacity with which they reinforce each other are examined. During Canada's early years, the name "Canadian" applied only to the nation's French. English Canadians were British. Working chronologically and using literary examples set in the context of their day, this essay demonstrates the resentment felt by French Canadians over Loyalism's grip on their Englishspeaking compatriots. Does Canada's continued adherence to the British monarchy keep Canada divided and prevent a sense of common nationality?
\end{abstract}

\section{Résumé}

Le Canada perpétue depuis longtemps deux mythes, à savoir le loyalisme et la conquête. La nature de ces mythes ainsi que leur fondement historique et la ténacité de leurs liens réciproques sont examinés ici. Dans les premières années du Canada, le terme "Canadien " désignait exclusivement des Canadiens français, alors qu'on appelait les Canadiens anglais, des Britanniques. La présente étude démontre, selon un ordre chronologique et à l'aide d'exemples littéraires replacés dans le contexte de leur époque, le ressentiment des Canadiens français à l'égard du loyalisme dont faisaient preuve leurs compatriotes anglophones. Est-ce que l'adhésion du Canada à la monarchie britannique divise toujours le Canada et l'empêche d'avoir un sens de nationalité commune?

The Conquest and Loyalism are Canada's two long-standing national myths, myths that have waxed and waned throughout the nation's history, but have tenaciously gripped the minds of its French and English-speaking peoples. Using literary examples from sequential periods of time, this paper will examine the long-term attitude of French Canadians towards the nation's British connection, the foundation on which Loyalism has rested.

French colonists in North America were known as Canadiens since the early days of New France and retained the name after they were conquered by the British in The Seven Years' War (1756-1763). Two decades later, refugees, fleeing the American Revolution (1775-1782), arrived in the northern colonies. They included natives and former slaves, but were 
mainly British, loyal to the Empire. During much of Canada's early history "Canadian" meant only the French. Over the years, the Conquest has acquired mythical status among French Canadians and has probably gained strength since Quebec separatism became a serious public issue. Loyalism, on the other hand, has steadily diminished in importance until many young people and new Canadians are hardly aware of such a myth. However, Canada's continued adherence to the British monarchy and strong anglophilia among English Canadians testifies to the still vital presence of Loyalism on the Canadian scene.

Traumatic events, usually wars, are the typical source of national myths. For Canada's French and English, there were two different wars that sparked two conflicting myths. The British triumphed in the first, the Seven Years War (1756-1765), but were the losers in the second, the American Revolution. The British and the conquered French had made little progress adapting to each other when Loyalists from the American Revolution arrived. Religious and linguistic differences accentuated conflicting attitudes toward British laws and customs: an alien way of life for the French versus the devotion to that way of life, which had cost the Loyalists their homes and livelihoods. This was an ominous beginning for two groups, forced to live together and faced with the daunting task of building a nation.

National myths are a sub-genre of the field of the history of ideas. A.O. Lovejoy, in his classic work, The Great Chain of Being, describes the history of the idea of the universe as a hierarchical chain, with God af the top, then descending through levels of angels, classes of humans, animals, other life forms and, finally, inanimate objects. This idea dominated Western thinking for many centuries. National myths differ from Lovejoy's God-centred, religion-based idea-and from classical myths that derive from ancient religions - in that they are confined to a national or tribal group and were formed out of one or more historical events. Like all myths they display longevity, ability to adapt to changed conditions, and have a tenacious hold on believers. Denis de Rougemont, in Love in the Western World; claims that a myth issues from "whatever sacred principle has presided over the formation of a group"; it is an "anonymous expression of collective," or common facts, and "disarms all criticism." The "most profound characteristic of a myth is the power which it wins over us, usually without our knowing" (de Rougemont, 1940, 18-19).

De Rougemont says that a myth will persist even if the "framework" disappears. It is "not the myth in its original guise, but that need of a myth which ... remains historically permanent" (de Rougemont, 1940,23). For French Canadians, there has always been a deeply felt need to maintain the Conquest as a defining event in their past. Also, because of repeated overt attempts to assimilate them, English Canadians are widely seen as continuous would-be conquerors. It has been nearly impossible for those 
who embrace the myth of the Conquest to sympathize with the countervailing Canadian myth, Loyalism, based as it is on familial devotion to Britain and the British, accentuated by fear and dislike of an aggressive United States. The Loyalist myth makes the Conquest appear to English Canadians as a remote historical event clung to by an incomprehensible people, impossible to satisfy.

The procedure for unmasking a particular nation's myths calls for a combination of historical and literary discourse at sequential time periods. National myths thrive as an interface between the exactitude of history and more open ended literary expressions. Lovejoy claims that "it is to literature we must look" in tracing ideas through a culture (Lovejoy, 1960, 17), and novelist Guy Vanderhaeghe says: "if you're going to look to literature to explain the past, you read an old book not a new one" (Aurora Online, 2003). Literature is always in some sense addressed to the audience of its day, the most vivid images of contemporary thinking sometimes appearing in popular works that lack literary sophistication. The written works examined in this paper - widely read and influential in their day-will each be set in the context of its time.

Often overlooked in today's culture is the gradual evolution of the designation "Canadian" to include the nation's English speakers. In the nineteenth century the English in Canada considered themselves British, living in an outpost of the Empire. Later in the century, when they began calling themselves Canadians, the term was inseparable from their British identity. After World War II, most English Canadians began seeing themselves solely as Canadians, so many French Canadians switched their identity to Quebec. Guy Rocher claims that "the rise of an EnglishCanadian nationality ... appeared more threatening to the Francophone minority than the imperial conception of the British Dominion of Canada" (Meiser, Rocher, 1999, 22).

A second historical fact, often overlooked today, is the nineteenthcentury popularity of manifest destiny in the United States. ${ }^{1}$ It exerted pressure on all Canadians to maintain strong ties to the Empire, seen as their only protection from an aggressively expanding southern neighbour. The United States was the monster at the gate for both English and French, but for somewhat different reasons. The Loyalists referred to the early United States as a mobocracy and anarchy let loose, a rowdy and dangerous people who had rejected their beloved British Empire. The "Loyalists stood, not for England and King George, but for Unity of the Empire ... they were antiAmerican by conviction and experience" (Stewart, 1985, 6, 5). For the French, there was nothing in U.S. law that would protect French language or culture. More serious was the American hostility to Catholicism. In the nineteenth century, both Canada and the United States considered themselves Christian nations, but to Americans this meant only Protestant. Alfred Kazin notes that the innumerable religious sects that sprang up in the 
early United States were "split on every doctrinal issue" except their "hostility to Cathọlicism, the Whore of Babylon" (Kazin, 1998, 13). Thus, French Canadians did not consider it desirable to break ties with the Empire until Canada could stand alone as a nation.

Before the Quiet Revolution of the 1960s, the Quebec license plate bore the motto La belle province [the beautiful province]; in 1976 it was changed to Je me souviens [I remember]. The objection to the old motto was that it labelled Quebec a province. The Quebec government claimed that the original agreement to create a nation was a contract between two founding people; deux nations they call it. This difference of historical interpretation between French and English Canadians remains unresolved today. To most English Canadians, there are strong legal reasons for not treating one province differently from another and the whole matter belongs in history's dustbin. In Quebec, they remember.

Among the things French Canadians remember is the monumental history of New France: the founding of Quebec City in 1608, the courage and ingenuity of the early settlers, and their creative relations with many native tribes who helped them survive in a northern wilderness. The French explored and traded in the heartland of the continent before the English had ventured beyond the Alleghenies. Why should a people with such a past be reduced to a small minority in a sea of English-speakers, people who have repeatedly tried to assimilate them? To the disaffected of Canada's French, a frequent answer is oppression by the British.

The Seven .Year's War transferred approximately 65,000 FrenchCatholic settlers to British control. The Royal Proclamation of 1763 changed the name of the colony from Canada to Quebec, decreed British laws and institutions, ${ }^{2}$ and set strict western boundaries to all of the North American colonies, hoping to force settlement northward to dilute French Catholic ways. James Murray, the first British governor of Quebec, seeing British laws and institutions as impracticable, did nọt implement them. (Mann, 2002, 34-36). The British government later legalized the Catholic religion and French civil laws in the Quebec Act of 1774. This Act also enlarged the borders of Quebec to include the Ohio valley. Settlement west of the Alleghenies was prohibited and no legislative assembly provided. The British were trying to protect the fur trade by avoiding wars with the natives and to pacify the French, whose loyalty was vital when the English colonies were threatening to revolt. The American colonists were outraged. They had little involvement in the fur trade, considered Catholicism the seat of the devil, ${ }^{3}$ and pressure for land was intense. The Quebec Act is considered a major cause of a majority of Americans opting for independence. There is a direct reference to it in the Declaration of Independence. ${ }^{4}$ The Quebec Act served one of its purposes, however, as the Bishop of Quebec decided that his people were better off under the British than joining revolting colonies that had almost no tolerance for Catholicism. 
Approximately 40,000 Loyalists were exiled to Nova Scotia and Quebec following the American Revolution. Quebec was without British institutions as Parliament had been uncertain what to do with their Frenchspeaking Catholic subjects whose lifestyle was so at odds with British ways. The Constitution Act of 1791 divided Quebec into Lower Canada and Upper Canada, each with a governor, appointed executive and legislative councils, and an elected assembly. Most of the Loyalists were settled on land in Upper Canada. Although French Canadians were by no means dominated by the church, all were Catholic and, as Jean-Pierre Wallot has shown, were "unmistakably cast in the mould of the French Regime" (Wallot, 1971, 52). ${ }^{5}$ The governor appointed only compliant French to the councils and not too many of those. Although the French dominated the assembly in Lower Canada, the legislative council made it more difficult for the assembly to withhold money, assuring early and bitter struggles. The French quickly learned to use this new British institution to frustrate the English. They would not allow land taxes and insisted on taxing commerce, to the outrage of Montreal's English merchants. Louis-Joseph Papineau led the assembly for much of the early nineteenth century, now a French/English battleground, and managed to halt public works and withhold government salaries. To the French, English speakers were their conquerors, a people who not only shunned Catholicism but were trying to force an alien way of life upon them. Both Papineau and the governor, Sir James Craig, appealed to the British. Parliament sided with the governor. Craig's name survives among French Canadians as a symbol of English oppression (Morton, 2001, 29).

The end of the American Revolution marked the beginning of the dual nature of the future Canada. The sense of grievance that characterized both parties was accompanied by a powerful sense of the past, a feeling that each had a European heritage that should have placed them in the forefront of world civilization. They sought protection in their perceived vulnerability. The French Revolution and the Treaty of Ghent (1816), ending the Napoleonic Wars, terminated any hope the French might have had of being returned to France. A shortage of priests, pressure to convert to Protestantism, and political battles between the government of Lower Canada and the parti canadien added to their woes (Wallot, 1971, 66-71). The Loyalists were "a flood of bitter, defeated exiles, who had suffered much and lost everything for the Crown" (Morton, 2001, 65). ${ }^{6}$ They expected the Empire to protect them and compensate them for their losses. Their descendants became increasingly and, by the late nineteenth century, almost fanatically loyal. Thus were born Canada's intractable national myths: Loyalism and the Conquest.

The most famous early novel to illustrate French-Canadian attitudes toward the English is Phillip-Joseph Aubert de Gaspé's Canadians of Old [Les Anciens Canadiens], published in 1863 and translated into English in 1864. This enormously popular novel has been used as an educational tool 
in Quebec schools for generations. Set before, during, and after the Seven Year's War, it tells the story of two young men, schoolmates and close friends, who fight on opposite sides in the war. Jules d'Haberville is French, the son of a seigneur; his friend, Archibald Cameron of Lochiel, is the son of a French mother and a Highland chieftain, killed at the Battle of Culloden in 1745. Archie was raised in France and educated in New France. His ancestral lands have been restored to him, so he is commissioned with the British army. Before taking up their new positions, the friends have an interlude with Jules's family. All is love and peace in this seigneurial system, with devoted habitants and a responsible upper class. Archie is like an adopted son to the family.

When the Seven Years War begins, Archie begs not to be sent to New France, but his knowledge of the country and fluency in French are valuable to the British. He is required to fight and ordered, on pain of death, to burn all of the homes, including the d'Haberville's manor house. The best he can do is to warn the inhabitants to flee.

After the war, Archie sells his Scottish lands and returns to New France. He had saved Jules' life during the war and threatened to resign his commission if the d'Habervilles are exiled to France, yet reconciliation is slow and incomplete. Gradually the family softens, so Archie and Jules are again like brothers, but when Archie proposes to the daughter, Blanche, she rejects him emphatically: "How can you make such a proposal when the fires that you and yours set throughout my unlucky country are barely out? ... there is a gulf between us that I will never cross." Blanche admits that she loves him, but is convinced that it is her duty to reject him. "The women of my family ... have never flinched from doing their duty or turned away from any sacrifice." When her brother urges her to change her mind she responds with the cry: "Am I, a d'Haberville, to set the example to the noble daughters of Canada by being twice conquered?" (Aubert de Gaspé, 1996, $217,219,241)$. The original conquest is now axiomatic; to marry a man named Cameron would be a second humiliation, a living symbol of a sellout. Blanche's inspirational words emphasize the myth of the Conquest and the danger of everything British. Loyalism was seen as a major threat when de Gaspé was writing his novel.

The popularity of Canadians of Old in the hands of the small, dominant, literate clergy and middle classes undoubtedly was used to project a model of behaviour that helped to keep the majority of uneducated nineteenth-century French Canadian habitants on the land, away from higher education, and technologically backward. French writers concentrated on the agrarian novel - le roman du terroir - that, as Paul Perron says, was "the most widely published genre of the first century of literary production in Quebec" (Perron, 2003, 152). 
The agrarian novel was introduced by Patrice Lacombe in 1846. La Terre paternelle established a pattern that lasted over one hundred years. The novel tells of the disasters that befall a family that leaves the ancestral farmlands to strive for wealth and higher social position in the town, then the city. With each move further from the farm, the family becomes more miserable and poverty stricken. One son dies and the family faces starvation before the second son, a voyageur, finds them and returns the family to rural happiness. This influential novel has never been published in English, testimony to the tenacious cultural gap between French and English Canadians.

The two nations concept that is still important to French Canadians has historical precedent. From the creation of Upper and Lower Canada in 1791 to the middle of the nineteenth century, the French formed a majority in the Canadas. The revolts of 1837-1838, promoting republicanism in both Lower and Upper Canada were put down by the British and Lord Durham was sent from England to try to resolve the situation. He recommended a uniting of the two provinces and equality between the two peoples. The Act of Union of 1841 created a single legislature for both provinces, now to be called Canada East and Canada West. English was the prescribed language (McRoberts, 1997, 22, 64).

Durham's 1839 report states that he found "two nations warring within the bosom of a single state"-progressive English versus French who embraced a "narrow" and "petty ... nationality," with "the unreasoning tenacity of an uneducated and unprogressive people" (Read, 2004, 189). Durham's scant respect for French Canadians led to the unashamed objective of trying to put them into a minority situation so that they would be outvoted and gradually assimilated into an English-speaking world. The Act of Union was seen by many in Lower Canada as an attempt to destroy their culture. It has never been forgotten in Quebec, in spite of the fact that it achieved no such objective. At the time, Lower Canada had a larger population than Upper Canada, but the law required equal representation. This was, in effect, two nations, equal representation of French and English. Durham claimed that Canada's French were a people without a literature or a history. In response, François-Xavier Garneau (1809-1866) wrote his monumental Histoire du Canada depuis sa découverte jusqu'a nos jours that appeared in four volumes, 1845 to 1852 . The Act of Union lasted until Confederation, twenty-six years.

In the early 1860 s, the American Civil War was raging. Confederation of all of the British provinces was seen as the best possible security once the Americans could turn their eyes to the north. By this time the population of Canada West had surpassed that of Canada East. Confederation would end the equality of French and English, would put the French in a clear minority position, and was unpopular with the French-speaking populace. GeorgeÉtienne Cartier (1814-1873), leader of the French federalist forces, was 
able to enlist the support of the Catholic bishops and to persuade his fellow government members to agree. He had won major concessions from the English: the French language, civil code, and Catholic religion were guaranteed, plus a fixed percentage of Supreme Court justices. By stressing that there was no alternative except annexation by the United States, Cartier 'was able to overcome the opposition's alarmed cry that the French could never again hope to be equal partners with the English; that they might even, someday, be forced to take up arms against their will (Mann, 2002, 109). Carl Berger points out that "Confederation was the creation of a political nationality, not a nationalist state. Sectionalism and communal diversities were not obliterated by the union.... The focus of political loyalty lay with the monarchy" (Berger, 1986, 253).

John A. Macdonald (1815-1891), soon to be Canada's first prime minister, claimed that the Americans had shown that federalism could not work (Morton, 2001, 92), so Canada should have a strong central government. Although his friend, Cartier, insisted on a federal system and the provincial powers that had been guaranteed to Lower Canada, Macdonald essentially triumphed. Residual or unspecified powers went to the central government and provincial laws could be suspended or even disallowed by the central authority. Provincial revenues were limited to direct taxes. The "fathers" of Confederation carefully avoided any such democratic horror as a referendum (Mann, 2002, 109). Confederation is now looked upon by Quebec separatists as a close second to the Conquest in the defeat of French Canada.

French Canadians still saw the British Empire as their best protection, for "le danger d'annexion aux États-Unis était toujours présent, et ... l'empire protégeait le Canada français non seulement contre les États-Unis mais surtout contre les projets d'assimilation du Canada anglais" [the danger of annexation to the United States is always present and the Empire protects French Canadians not only from the United States but above all from English-Canadian assimilation projects] (Silver, 1981, 68-69). Assimilation of the French was popular in English Canada and, as repeated political crises raised hostility levels in both groups, ${ }^{7}$ French Canadians turned toward the Catholic Church with increasing enthusiasm. In the second half of the nineteenth century, "French-Canadian élites proposed that the divine mission of the people was to be Catholic and rural" (Robert, 2004, 251). In 1875 , the bishops of Quebec issued a pastoral letter stating that not only is "the Church independent of civil society, but is superior to it" (Thorner, 1998, 138). A romanticized rural lifestyle was promoted by the Church and accepted by the people. Immigrants from English-speaking countries were pouring into the country and Catholic authorities, concerned for the survival of French culture, language, and religion, believed the only solution was to avoid contact with the English and maintain a high birth 
rate, a tactic that came to be known as "revenge of the cradle" (Clift, 1989, 53).

Maria Chapdelaine (1916), by Louis Hémon, ${ }^{8}$ is the best known example of the agrarian novel. Now a Canadian classic that has been translated into many languages, it differs from most agrarian novels written before the mid-twentieth century in that it does not glorify rural life. Maria Chapdelaine lives with her family on a primitive farm in the hinterland of Quebec. She is so capable, healthy, and attractive that she receives three marriage proposals in a year. The first suitor, François Paradis, she loves and has secretly promised to marry. He has sold his family farm and lives as a woodsman and fur trader. She says a thousand prayers for his safety, but the overconfident young man loses his way in a winter storm and freezes to death. The second suitor, Lorenzo Suprenent, has sold his family farm and works in a mill in Massachusetts. He tempts Maria with stories of lights, shops, and a life free of the unceasing drudgery that she has always known. The third suitor, Eutrope Gagnon, lives on a neighbouring bush farm. With him she would continue her present life: "do the housework and the cooking, milk the cows, clean the stable ... spend her evenings at the spinning wheel or in patching old clothes," and during brief rests to look "across their scant fields girt by the eternally frowning woods ... closed round them with a savage grip that must be loosened little by little, year by year" (Hémon, 2004,95). She decides that she cannot face it and will accept Lorenzo.

The two suitors that Maria chooses to marry have both sold their family farms, an ominous sign in the agrarian novel. In addition, Maria discovers that her own wishes are of little significance. After the death of François, the local priest takes Maria aside and tells her that her grieving is "a sacrilegious thing and unseemly" and that she must stop "casting gloom over the household." When she decides to escape her gruelling life by marrying Lorenzo, her mother dies suddenly and painfully. Conscious of a now motherless young sister and listening to her grieving father, Maria hears voices. The first voice tells of the wonders of nature and the changing seasons; the second speaks of "a strange land where people of an alien race spoke of unfamiliar things in another tongue"; and the third is "the voice of Quebec." This voice is "mightier than the others ... the soul of the province: the loved solemnities of the ancestral faith; the lilt of that old speech guarded with jealous care; the grandeur and the barbaric strength of this new land where an ancient race had again found its youth." She is told that her "one duty" is to "hold fast ... endure." She must "hand on to descendants ... this land of Quebec [where] naught shall die and naught shall suffer change." She wakes as from a dream: "So I shall stay-shall stay here after all." The decision has been made for her and Maria accepts. She tells Eutrope that she will marry him. Maria had dared to dream of love and of a better life but, like Blanche d'Haberville, she recognizes her duty and accepts the life assigned to her (Hémon, 2004, 80, 123-127). It is the second 
voice, speaking of "an alien race" and "unfamiliar things in another tongue," that warns of the danger of the English to a conquered people.

All Canadians felt endangered in the late nineteenth century as manifest destiny was at a peak in the United States. Walt Whitman (1819-1892), known widely as the poet of manifest destiny, was assuring Americans that "ere the second centennial arrives, there will be some forty to fifty great states, among them Canada and Cuba.... The Pacific will be ours and the Atlantic mainly ours" (Whitman, 1948, II, 250).

English Canadian loyalty to the Empire was never higher. John A. Macdonald won the Canadian federal election of 1891 with the ringing cry, "A British subject I was born, a British subject I will die." This won the hearts and minds of most of Canada's English-speaking citizens. As British subjects they could face the hated Americans and the Empire would save them from annexation. There was, however, the occasional dissenting voice among the English. Goldwin Smith (1823-1910), author of Canada and the Canadian Question (1891), argued for union with the United States, partly on the grounds that the Americans could accomplish what English Canada could not: assimilation of the French.

Imperial Federation was a widespread and popular concept among English Canadians around the turn of the century. It saw Canada's future as an integral part of the British Empire, on a par with England or Scotland (Morton, 2001, 173). To English Canadians it was their Empire as much as Britain's Empire (Berger; 1970, 71, 89). The Imperial Federation League, founded in London in 1884, rapidly established branches in Canada, where the "loyalist tradition" provided "one of the most potent elixirs to Canadian imperial sentiment." The "descendants of the loyalists were to constitute the major source of the League's support" (Berger, 1970,78). In 1902 Henri Bourassa (1868-1952), grandson of Louis-Joseph Papineau, tried to explain how French Canadians felt about such a prospect: "How thoroughly and exclusively Canadian the French-Canadian is should never be forgotten by those who contemplate any change in the constitutional or national status of Canada ... Toward the Empire he has no feelings whatsoever and considers English speakers as only "partially Canadianized" (Thorner, 1998, 122-23). Bourassa was a principal spokesman for the view that Canada should be working toward complete independence (Morton, 2001, 155). It was in this atmosphere that English-Canadian writer Gilbert Parker published his popular novel, The Seats of the Mighty, in 1896.

The heroine of this historical romance set during the Seven Years War is a French-Canadian girl, Alixe Duvarney, who saves her British lover, Robert Morey; who has been imprisoned as a spy. What a heroine! She slips past guards, disguises herself as a soldier, later as a nun, lies and schemes like a professional, and finally dances to distract Morey's would-be executioners. She is secretly married to him. by a Protestant minister. With Alixe's help 
Morey escapes, joins General Wolfe, leads the British up the cliffs, and is unable to avoid killing Alixe's brother during the battle of the Plains of Abraham. Early in his imprisonment, Morey wonders about Alixe's father, for what "Frenchman would care to have his daughter lose her heart to one accused of a wretched crime, condemned to death, an enemy of his country and a Protestant?" When Alixe's actions are discovered, she is brought before the Bishop, her marriage is annulled, and she is imprisoned in a convent. She defiantly replies: "I am sorry that I have offended my people and my country and Holy Church, but I do not repent that I love and hold to my husband." When the lovers are reunited after the war, Seigneur Duvarney welcomes his son-in-law and all are happy in the arms of the British Empire. The contrast between heroines Blanche D'Haberville and Maria Chapdelaine, created by French writers, and Alixe Duvarney, imagined by an English writer, is a measure of the hardening of those myths of Conquest and Loyalism (Parker, 1971, 58, 169).

The Boer War began in 1899 and Canada, a loyal member of the Empire, was expected to send troops. This was the first French-English conflict over sending Canadian youth to a foreign war, a mere prelude to the conflicts of World War I and the federal government's imposition of conscription in 1917. So divided were French and English over the conscription law that all French members of the Federal government were either defeated or resigned. The English ruled supreme and separation of Quebec from Canada began to be seriously considered.

French-Canadian nationalism in the first half of the twentieth century was based on a "vision of Canada" that, as Guy Rocher says, was more a "project" than a reality. The immediate concern was French primary and secondary schools in provinces other than Quebec. Decisions in New Brunswick, Ontario, and Manitoba to cease funding French Catholic schools were direct attacks on the French dream of a "bilingual Canada" in which the two linguistic groups would work together to build "a country that belonged to them - a truly independent country." Not only did the French nationalists make many requests and demands on the subject of nationwide French schools, but they insisted that Canada should leave the British Empire. Such things as legal appeals to the Privy Council in London, designating Canada a Dominion, holding British citizenship, and clinging to the monarchy were denounced as "archaic ties" from which Canada should free itself. The Union Jack as the Canadian flag was called a "humiliating" symbol of "outdated colonialism." None of this appears to have been taken seriously in English Canada. In 1925, Prime Minister Mackenzie King raised the subject of Canada getting its own flag. In the House of Commons he was accused of "disloyalty to the Mother Country" (Meiser, Rocher, 1999, 175-176).

A number of intellectual and nationalistic groups and publications were started in the wake of World War I. Abbé Lionel-Adolphe Groulx (1878- 
1967), probably the most famous French-Canadian historian of the twentieth century, is widely seen today as the father of Quebec separatism. Groulx was a teacher, writer, and editor of $L$ 'Action française. His novel, The Iron Wedge [L'Appel de la race] (1922) went through numerous editions and was highly controversial. Little read today, it created a major stir in the 1920s. Highly polemical, the novel tells the story of Jules de Lantagnac, a successful French-Canadian lawyer living in Ontario, married to an English Canadian, and father of four. The time is the early days of World War I and Jules, in his early forties, has recently visited his longneglected Quebec family and become guiltily aware of his FrenchCanadian heritage. Encouraged by Father Fabian, an Oblate priest, he comes to the conclusion that he made a serious mistake marrying an English woman and that he is morally obligated to enter federal politics in defence of French educational.rights in Ontario, even at the expense of breaking up his family.

Father Fabian makes the case for the primacy of Lantagnac's duty to his people, insisting that "the perceptible, visible, tangible truth ... is that there is in this country a relentless intention to eliminate us." Father Fabian's argument is bolstered by symbols and comments from the English. The "conqueror's flag waved arrogantly" over the Parliament buildings when Lantagnac returns to Ottawa, his hostile son writes "Rule Britannia for ever!" on the flyleaf of a book about French-Canadian history, and his estranged wife persuades the Women's Welfare League to replace the singing of $O$ Canada with God Save the King. When Lantagnac speaks of Canada, he means only French Canada. Addressing Parliament, he tells his audience: "You, the Anglo-Saxons, are imperialists; we, the sons of Canada, are above all Canadians" (Groulx, 1986, 49, 169, 164, 157).

Jules is moved by a sculpture showing Robert Baldwin (1804-1858) and Louis-Hippolyte La Fontaine (1807-1864), first leaders of the United Canadian provinces, discussing a historic document: "Here is depicted neither a conqueror nor one who is vanquished, neither a superior race nor an inferior one. Equal is treating with equal." The novel ends hopefully as Lantagnac sees the "time approaching when his people ... in full possession of their destiny, take up the ancient dream of the days of New France" (Groulx, 1986, 141, 163).

Groulx's stance was bolstered in 1925, when former prime minister, Arthur Meighen, told an audience that Canada was "ready, aye ready" to join its motherland, Britain, in any wars the Empire might find it necessary to embark upon. Meighan's Conservative party promptly lost any remaining support in Quebec.

English-Canadian writer, Hugh MacLennan (1907-1990), understood both French and English viewpoints. ${ }^{9}$ His now classic novel, Two Solitudes (1945), covers two generations, from late in World War I to the beginning of 
World War II. The protagonists, Athanese Tallard and his half-English son Paul, try to bridge the gap between the two cultures. Athanese dies a ruined man and bilingual and bi-cultural Paul becomes a man almost without a country. There are characters on both sides who articulate extreme but widespread views: Father Emile Beaubien for the French and Janet Metheun for the English.

Father Beaubien, priest in the rural Quebec parish of Saint-Marc-desÉrable, is angry with Athanese Tallard, the largest landowner, Member of Parliament, and descendant of the parish seigneurs. Tallard had sold some land to an Englishman and is making plans to open a factory. It is 1917 and Father Beaubien "thought of the war and the English with the same bitterness. How could French Canadians-the only real Canadians-feel loyalty to a people who had conquered and humiliated them, and were Protestant anyway?" He tells Tallard that he will not allow him to "spoil this parish" by bringing in the English. Finally they face each other before the villagers. The priest tells the people that Tallard is "no longer a good Catholic" and that "God will not bless them if they elect a man" like him. Tallard leaves the parish and the Catholic Church, moves to Montreal and joins the Presbyterians. He sends Paul to an English boys' school where the students are told that their country is "not Canada but the British Empire" (MacLennan, 1967, 6, 167, 184-185, 232).

The English business world is seen in microcosm in an elevator in the Bank Building in Montreal. It is precisely two minutes to nine-thirty on Monday morning and the elevator is full of impeccably dressed men who control most of Canada's finance and industry. They are "Presbyterians to a man." In the heart of this world lives Janet Metheun, arrogant daughter of the kindly old sea captain who bought land from Tallard. Janet "worked on every war committee in Montreal ... and was careful to allot herself the same rations allowed people in Britain. To make herself feel worthy of the British she was prepared to go hungry." The Metheun family considered itself "an extension of the British Isles." They prided themselves on "never making a display"; they "incubated their money, increasing it by compound interest" and "no one could possibly mistake them for Americans" (MacLennan, 1967, 104, 112, 148-149).

On a visit to her father, Janet tells the military police where Tallard's son by his first wife is hiding. When her distressed father tells her that she doesn't "understand these people," she has "never tried to," she replies angrily that its time these French Canadians were "brought to heel" (MacLennan, 1967, 186-187). Janet is finally defeated when her younger daughter marries Paul Tallard.

In 1960 the liberal government of Jean Lesage initiated the Quiet Revolution, took education and most social matters away from the Catholic Church, and began a rapid modernization. With breathtaking speed, 
Quebec moved from being the most socially conservative province in Canada to being the most liberal, the birth rate dropped below the replacement level, and Lesage's government demanded special status for Quebec. Since this Quiet Revolution, French-Canadian writers have turned on the Catholic Church with a vengeance. ${ }^{10}$ Anger with the Church, however, has not lessened the sense of bitterness toward the nation's English.

Gratien Gélinas' 1967 drama, Yesterday the Children were Dancing [Hier, les enfants dansaient], depicts a bitter generational conflict in the home of Quebec lawyer, Pierre Gravel - a federalist versus separatist fight that followed hard on the Quiet Revolution. Gravel has been asked to replace the suddenly deceased Minister of Justice in the federal government, at the same time that news arrives of a bomb destroying a statue of General Wolfe in Quebec City. Anxious to accept the position in Ottawa and convinced that separation would be economic suicide for Quebec, Gravel discovers that his eldest son, André, is leader of the group that planted the bomb. Andre gives his reasons for the bombings, reasons directed at the English. Every day until the coming election a "symbol of British Imperialism" will be destroyed. André dismisses his father's arguments as coming from one who "grew up in a colonial world, where submission to the English and licking their boots were ... national virtues." As the dispute winds down, news arrives that a statue of Queen Victoria has just been blown up, the bomb exploded by the Gravel's younger son. Gravel is no longer eligible for the position in Ottawa, but is scheduled to speak to the Canadian Club in Toronto the next day. He suddenly settles on the conclusion to his talk: "my divided house will not go down without shaking yours to its very foundations" (Gélinas, 1967, 45, 46, 60-61, 76). This drama is uncompromising in its assertion that Quebec's troubles are rooted in British imperialism.

Gélinas's play could hardly have been more timely, for several nationalist groups founded the Parti Québécois (PQ) in 1968, under the leadership of Rene Levesque, dedicated to the separation of Quebec from the rest of Canada. In 1976 the PQ became the government of Quebec, changed the motto on the licence plate, and five years later held a referendum on sovereignty-association that was defeated. Writer Hubert Aquin (1929-1977) was an early acolyte on the nationalists' team. In 1962 he published two essays explaining the need for Quebec to become a separate nation. ${ }^{11}$ Aquin speaks of federalists and nationalists as the two poles in Quebec politics - father and son in Gélinas' play-and claims that French politicians have been misled by the English into becoming negotiators, not revolutionaries. They spend their time asking Ottawa for more rights, typical of the "French Canadian-conquered in every fibre of his being." Claiming that French culture has been reduced by the English to the arts, he says that Confederation can function smoothly only by 
assimilating the French, "not two cultures but ten provinces." Aquin acknowledges his "ill feelings" toward "English Canadians" and echoes Groulx when he wonders who will realize the Québécois "dream" and lead them to the "Promised Land" (Aquin, 1988, 8, 9, 13).

Michel Marc Bouchard's 1995 drama, The Coronation Voyage [Le voyage $d u$ Couronnement], has been performed across Canada in both French and English, notably at the Shaw Festival in the summer of 2003. The setting is a passenger ship, The Empress of France, sailing to England in 1953 for the coronation of Queen Elizabeth II. Among the passengers is a French-Canadian MP, Minister Joseph Gendron-along with his wife and daughter-who is to represent Canada at the big event. Besides the irony implicit in the name of the ship, those going to the coronation are being instructed in protocol by a Mademoiselle Lavallée. The minister's wife, Alice Gendron, is an embittered woman, with two sons killed and a third permanently crippled in World War II. On several occasions she throws a scene, embarrassing her husband and daughter. Initially she is sarcastic, telling Mlle Lavallée to get them better seats for the coronation: "We gave three sons to England, that must be worth three good seats for the show." The death of their sons at Dieppe is explained as a British error of judgment that the Canadian government failed to protest: "Hardly surprising from a country that still acts like a colony. Banknotes, stamps, parliament, the legislative system, all in the image of the imperialist monarchs" (Bouchard, 1999, 41, 84).

Minister Gendron begs his wife to forget what happened eleven years ago, but when she asks if he hates her he explodes: "You, who dares say aloud the words that haunt me; you, who have borne the insomnia, the grief, the loss of my sons .... you, all that is left of my conscious .... Of all the truths I know, there is only one I have never been ashamed of: I love you, Alice" (Bouchard, 1999, 120). Such words imply that, unlike Blanche d'Haberville and Jules de Lantagnac, Gendron has been a sellout, for he turned his back on the myth of the Conquest. Bouchard calls The Coronation Voyage his Canadian play.

The same year that Bouchard's drama was published, the second separatist referendum was held in Quebec. This time it was barely defeated: $49.4 \%$ yes, $50.6 \%$ no; with a majority of French Quebec voting yes. Canada came within a hair of being dismembered. The federal government had been totally unprepared. A giant rally in Montreal drew citizens from across the country. "We love you, don't leave us" seemed to be the message in the "My Canada Includes Quebec" rallies.

The rally in Montreal was driven by a sense of panic that suddenly overwhelmed the nation. Although the English in Canada professed an affection for French Canadians, the Québécois could not forget the national myths that had been perpetrated for over two hundred years. When Father 
Fabian, in The Iron Wedge, tells Jules de Lantignac that there is in Canada a "relentless intention to eliminate" the French, many French Canadians believe this is not a serious exaggeration. The Royal Proclamation of 1763 , which sought to divert American settlement north in order to dilute the French population, was followed by the Constitution Act of 1791, which established a system with an institutionally weak elected legislature. British law, reflecting centuries of religious conflict, kept almost all of Canada's French out of government positions. Lord Durham's promotion of the union of the Canadas in 1839 , with the express purpose of putting the French in a minority position so they could be outvoted and eventually assimilated, was sufficiently unsuccessful to inspire Goldwin Smith in 1891 to recommend that Canada join the United States, partly so that the greater English-speaking population to the south could achieve Lord Durham's objective. The Imperial Federation League was followed by the British Empire League, both seeking to make Canada an integral part of the British Empire rather than an independent nation. Prime Minister Macdonald's 1891 election cry, “A British Subject I was born, a British subject I will die," was followed a generation later by a former Prime Minister who assured the people that Canadians were "ready, aye ready" to die for the Empire and a sitting Prime Minister who was accused of disloyalty to the motherland for suggesting that Canada might get its own flag. Walter Stewart claims that the "Loyalists, quite simply, took Canada away from its original owners and rebuilt it" (Stewart, 1985, 5). That is an exaggeration and the original owners were the natives, ${ }^{12}$ but many events in the history of Canada have reinforced the myths of the Conquest and Loyalism. Perhaps the only reason that Quebec voters still have a sentimental attachment to Canada is that for a century and a half it was their country and for many generations afterward they were the only Canadians.

Imperial Federation and comments about loyalty to the mother country have long passed from the English-Canadian scene. Devotion to everything British, however, continues to run deep. Prime Minister Pierre Trudeau did not include ending the monarchy as part of his 1982 Constitution. When asked about it in a televised interview, his answer-that too many Canadians were still strongly attached to it-indicated a political impossibility,

In April 2007, a suggestion was made that the Queen be invited to visit Quebec on the 400th anniversary of the founding of Quebec City. The media was promptly inundated with outraged calls; an insult to Quebec was the overwhelming response. "We are celebrating the foundation of New France, not its conquest. The monarchy remains a symbol of imperialism and colonialism," said Mario Beaulieu, vice-president of Montreal's Société Saint-Jean Baptiste (Séquin, 2007, 5). The monarchy as a highly emotional divide that continues to plague the nation is surely disheartening to the many immigrants who have chosen to make'Canada their home, 
particularly those from countries like India, who spent so many years freeing themselves from British rule.

As Mme Gendron says: "Banknotes, stamps, parliament ... all in the image of the imperialist monarchs" (Bouchard, 1999, 84). Those of us who study a nation's history and traditions never underestimate the importance of myths and symbols. Images of the Crown are still legion in Canada and, though attachment to the monarchy is now largely sentimental among the English, it continues to be a factor stoking the fires of separatist aspirations.

\section{Notes}

1. A widespread belief among nineteenth-century Americans that God intended the United States to expand across the continent. As a recurrent political issue, that meant all of North America.

2. British law did not allow a Catholic to hold any government position.

3. Maryland and Pennsylvania were the only American colonies that tolerated Catholics and, even there, they were denied the franchise.

4. "For abolishing the free system of English laws in a neighbouring province, establishing therein an arbitrary government, and enlarging its boundaries so as to render it at once an example and fit instrument for introducing the same absolute rule into these Colonies."

5. Wallot points out that the ultra religious orders, which were to have so much influence on French Canadians from the mid-nineteenth to mid-twentieth centuries, did not arrive until after 1840 (Wallot, 1971, 52).

6. Much twentieth-century scholarship has countered the overblown images of the Loyalists perpetrated in late nineteenth century Ontario. See Carl Berger, The Sense of Power (1970) and Norman Knowles, Inventing the Loyalists (1997).

7. The most notable late nineteenth-century divisive issues were the hanging of Louis Riel, the Manitoba Schools crisis, English enthusiasm for Imperial Federation, and the Boer War.

8. Hémon was a Frenchman who spent several months living with and studying the Quebec peasantry before writing his novel.

9. MacLennan was greatly influenced by Ringuet's Thirty Acres (1938), a novel that vividly depicts the domination of the Catholic Church in rural Quebec, the many children expected, and the grinding poverty that resulted.

10. Anger with the church was anticipated with Ringuet's Thirty Acres (1938) and probably peaked with Marie-Claire Blais's novel, A Season in the Life of Emmanuel (1965).

11. "The Politics of Existence" (March 1962) and "The Cultural Fatigue of French Canada" (May 1962), (Aquin, 1988, 8-17, 19-48).

12. Canada was originally Kanatha, an aboriginal word

\section{Bibliography}

Aquin, Hubert. Writing Quebec: Selected Essays. Trans. Paul Gibson, Reva Joshee, Anthony Purdy, and Larry Shouldice. Edmonton: University of Alberta. Press, 1988.

Aubert de Gaspé, Philip-Joseph. Canadians of Old. Trans. Jane Brierley. Montreal: Véhicule Press, 1996. 
Aurora Online. "Prairie Storyteller: An Interview with Guy Vanderhaeghe." Saskatoon, SK, May 2003.

Berger, Carl. The Sense of Power: Studies in the Ideas of Canadian Imperialism 1867-1914. Toronto: University of Toronto Press, 1970.

Berger, Carl. The Writing of Canadian History: Aspects of English-Canadian Writing Since 1900. Toronto: University of Toronto Press, 1986.

Blais, Marie-Claire. A Season in the Life of Emmanuel. Trans. Derek Coltman. Toronto: McClelland \& Stewart, 1966.

Bouchard, Michel Marc. The Coronation Voyage. Trans. Linda Gaboriau. Vancouver: Talonbooks, 1999.

Clift, Dominque. The Secret Kingdom: Interpretations of the Canadian Character. Toronto: McClelland \& Stewart, 1989.

de Rougemont, Denis. Love in the Western World. Trans. Montgomery Belgion. Princeton: Princeton University Press, 1940.

Gélinas, Gratien. Yesterdày the Children were Dancing. Trans. Mavor Moore. Toronto: Clarke Irwin \& Co., 1967.

Groulx, Lionel. The Iron Wedge. Trans. J.S. Wood. Sth ed. Ottawa: Carleton University Press, 1986.

Hémon, Louis. Maria Chapdelaine. Trans. W.H. Blake. Ottawa: The Golden Dog Press, 2004.

Kazin, Alfred. God and the American Writer. New York: Vintage Books, 1998.

Knowles, Norman. Inventing the Loyalists: The Ontario Loyalist Tradition and the Creation of Usable Pasts. Toronto: University of Toronto Press, 1997.

Lacombe, Patrice, La Terre paternelle. Montreal: La Corporation des Édition Fides, 1981.

Lovejoy, Arthur O. The Great Chain of Being: A Study of the History of an Idea. New York: Harper \& Row, 1960.

Mann, Susan. The Dream of Nation: A Social and Intellectual History of Quebec. Montreal: McGill-Queens University Press, 2002.

MacLennan, Hugh. Two Solitudes. Toronto: Macmillan of Canada, 1967.

McRoberts, Kenneth. Misconceiving Canada: The Struggle for National Unity. Toronto: Oxford University Press, 1997.

Meiser, John, Guy Rocher, Arthur Silver, et al. As I Recall Si je me souviens bien: Historical Perspectives. Montreal: Institute for Research in Public Policy, 1999.

Morton, Desmond. A Short History of Canada, 5 th ed. Toronto: McClelland \& Stewart, 2001.

Parker, Horatio Gilbert. The Seats of the Mighty. Toronto: McClelland \& Stewart, 1971.

Perron, Paul. Narratology and Text: Subjectivity and Identity in New France and Québécois Literature. Toronto: University of Toronto Press, 2003.

Read, Colin. "Durham, John George Lambton, Earl of." The Oxford Companion to Canadian History, ed. Gerald Hallowell. Toronto: Oxford University Press, 2004.

Ringuet. Thirty Acres. Trans. Felix and Dorothea Walter. Toronto: McClelland \& Stewart, 1960.

Robert, Jean-Claude. "Quebec." The Oxford Companion to Canadian History. Gerald Hollowell, ed. Toronto: Oxford University Press, 2004.

Sequin, Rheal. "A birthday visit by the Queen? Quebecers are not amused." The Globe and Mail April 14, 2007: 1+.

Silver, Arthur I. "Quelques considérations sur les rapports du Canada français avec l'impérialisme britannique au XIXe siècle." Canadian Journal of African Studies 15:1 (1981): 55-75.

Stewart, Walter. True Blue: The Loyalist Legend. Toronto: Collins, 1985.

Thorner, Thomas. "A country nourished on self-doubt": Documents in Canadian History, 1867-1980. Peterborough ON: Broadview Press, 1998.

Wallot, Jean-Pierre. "Religion and French-Canadian Mores in the Early Nineteenth Century. The Canadian Historical Review 52:1 (1971): 51-94.

Whitman, Walt. "Democratic Vistas." The Complete Poetry and Prose of Walt Whitman, 2 vols. New York: Pellegrini \& Cudahy, 1948. 